\title{
瓦斯體ガ超音波ノ細菌破壤二及ボス影響蓝 ニコレガ應用抗元テ以テスル免疫學的研究
}

\author{
第 1 編 細菌死滅二關スル研究 \\ 神奈川縣中央衛生試驗所（主任 渡邊邀博士） \\ 醫學士 尾崎茂 樹 \\ Shigeki Ozaki \\ （昭和14年 1 月 13 日受付）
}

\section{【㐫 容 抄 錄】}

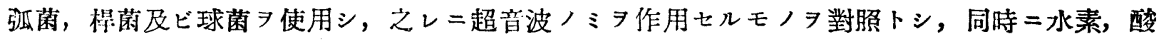
素, 筑素及ビ炭酸瓦斯

\section{目次}

緒諭

第 1 編 細菌死滅 $=$ 妝ス几研究

第 1 章 實驗方法並 $=$ 供試菌株

第 1 節 使用五斯ノ種類及瓦斯迼入装置

第 2 節 供試菌株

第 3 節 細菌死滅檢查

第 2 章 貿驗成績

第 1 節 水素无斯 7 以テンル實驗

第 1 項 弧菌 第 2 項 程菌

第 3 項 球菌 第 4 項 本節成績 小括

第 2 節 酸素瓦斯
第 1 項 弧菌
第 2 項 桿菌
第 3 項 球菌 第 4 項 本節成績,
小括

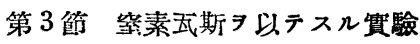

第 1 項 弧菌 第 2 項 程菌

第 3 項 球菌 第4項 本節成績，

小括

第 4第 炭酸瓦斯

第 1 項 弧菌 第 2 項 桿菌

第 3 項 球菌 第4 項 本節成紿，

小括

第 3 慞 結 諭

\section{緒論}

Langerin (1920年) Wood and Lomis (1927年) 等=ョリテ創始セラレタル超晋波裝置八 㗹テ微生物學方面へノ研究二應用七ラルル =至レリ. 即チ Wood and Loomis(1928年) E. N. Havery and Alfred L. Loomis(1931年) O. B. Willian and N. Gaines (1934年) . $N^{*}$ Takahashi and R.J. Christensen(1934年) H. Yaoi and W. Nakahara(1934年), 真田氏, 笠原氏等(1938年) /研究業績习觀ル。 
當試驗所 $=$ 於 ノ研究 企圖シ, 既=昭和 11 年ソレガ概要习發表シ, 次イデ翌年超音波抗元ノ感染防禦試驗 二就說述シ, 清水八昨年 4 月微生物學會二於テ赤痢超音波抗元ノ研究ノ一部 戶八超晋波 $=ヨ ル$ 細菌破壞作用二就キ詳細ナル研究業績ヨ發表シ, 余モ亦コレ二關シ實驗研 究セリ. 最近余八恩師渡逶博士等卜共二超亘波これら抗元及ちふす抗元 =就丰研究シ在來，

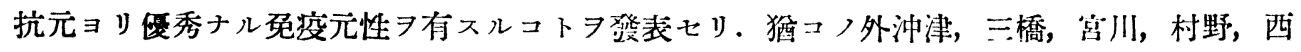
等ノ研究八各種ノ項目 $=$ 向フラ゙步ヨ進メ居レリ.

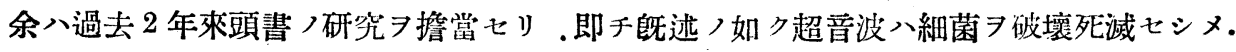

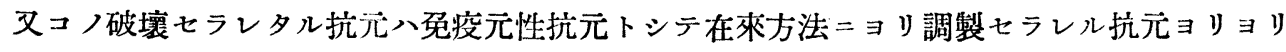
優秀ナリ.余ハコノ細菌浮游液 $コ$ 容レタル試驗管內二諸種, 瓦斯體 細菌死滅, 菌浮游液, 溷濁變化, 菌容量ノ增減=如何ナル影響习招來スルモノナルヤヌコレ 二因リテ得ラレタル抗元八乔疫元トシテ價值アルヤ否ヤ二就イテ攻究シタルモノナリ. 今コレガ研究ノ大體 ヨ完成シタルヨ以テ，茲＝單簡＝記述ヨ試ミ大方諸賢ノ叱正 トスルモノナリ

\section{第 I 編 細菌死隇二關スル研究}

\section{第 I 章 實驗方法並二供試菌株}

\section{第 1 節便用死斯ノ種類之豦斯送入裝置}

使用七ル瓦斯八, 水素, 酸素, 窒素及炭酸瓦斯ノ4 種=シテ何レモ鐵管＝厴縮セル市販賣 品 $习$ 購入シ其ノマア實驗

實驗用裝置トシテ余八第 1 圖ニ示スガ如キモ， フ使用セリ即チ A 八瓦斯 ヨ滿セル鐵管 B

第 1 圖五斯揆入裝置

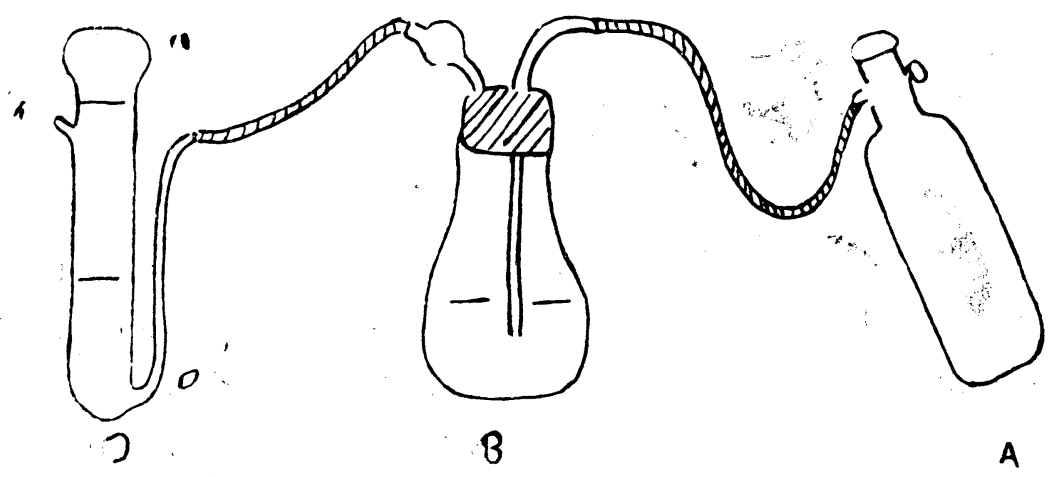


ヨ水ヨ容レタルこるべん， C 八余ガ考案製作セシメタル試驗管ニジテ，直徑 $1.8 \mathrm{~cm}$ 管ロヨ

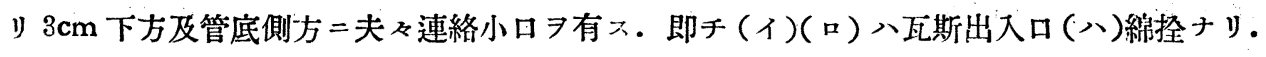
佾本試驗管，底部，硝子管壁入 $0.06 \mathrm{~cm}$ 內外卜ス. A 過シ次イテ C八菌浮游液 驗管 $=$ 菌浮游液 モノナリ.コノ際瓦斯ガ菌液ヨ通過スル量ハ 1 分間ノ氣泡數 20 ト七リ,

\section{第 2 節 供 試 菌 株}

供試菌株八 1), 弧菌トシテこれら菌(木谷株)及非病原性弧菌赤穗株， 2 菌種 2), 楻菌 トシテ腸ちふす菌, ぱらちふす $\mathrm{A}$ 菌, ぱらちふす B 菌, 鼠ちふす菌, 赤痢本型菌, 赤麻異 型 1 菌. 赤痢異型菌及大腸菌/8菌種 3 ), 球菌トシテ白色葡药狀球菌及溶血性連鎻狀球菌 2 菌種合計 12 菌株ナリ。

乔疫學的研膋トシテ代表トシテ只腸ちふす菌 $\mathrm{V}$ 型株ヨ使用七リ。

\section{第 3 節 細菌死隇檢查}

上記12菌株, 24 時間培養ノ菌苔 7 探リ之レ メ，之レ二超音波ノミヨ作用セルモノヨ對照トシテ，作用卜同時二瓦斯ヨ通ゼルモノト比較 シテ死滅ノ如何 7 檢七リ. 即于作用後, 菌液つ $5 / 100 \mathrm{cc} ト シ テ ， 48^{\circ} \mathrm{C}=$ 保テル寒天下良ク混

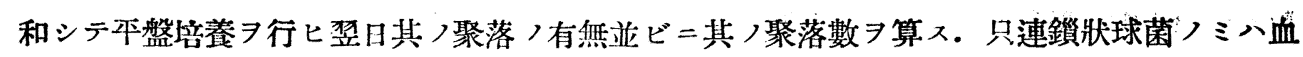

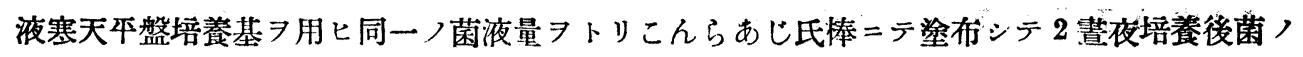
死隇狀態 7 憸

\section{第 2 章 實 驗 成 績}

\section{第 1 節 水素死斯ヨ以テスル實驗 \\ 第 I 項 弧菌}

弧菌!シテ畺正これら菌及非病原性弧菌赤穗株 =就キテ, 賽驗成績八第 1 表及第 2 表 $=$ 示 ス如シ.

第 1 表ここれら菌

\begin{tabular}{|c|c|c|c|c|}
\hline 作用法 & $\begin{array}{c}\text { 你角 } \\
\text { 譛度 }\end{array}$ & 10 分 & 20 分 & 30 分 \\
\hline 對炤 & $40^{\circ} \mathrm{C}$ & $\infty$ & ca. 500 & 0 \\
\hline 水素 & $40^{\circ} \mathrm{C}$ & $\infty$ & ca. 200 & 0 \\
\hline
\end{tabular}

第 2 表 赤穗菌

\begin{tabular}{|c|c|c|c|c|}
\hline 作用法 & \begin{tabular}{|c|c|c|} 
作用 \\
溫度
\end{tabular} & 10分 & 20 分 & 30 分 \\
\hline 對炤 & $41^{\prime} \mathrm{C}$ & $\infty$ & ca.1000 & 0 \\
\hline 水素 & $41^{\circ} \mathrm{C}$ & $\infty$ & ca. 300 & 0 \\
\hline
\end{tabular}




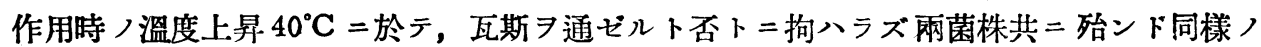
成績 八完全二死隇ス。

\section{第 2 項 桿菌}

腸ちふす菌,ばらちふす A 菌，ぱらちふす B 菌鼠ちふす菌ニ就キテノ實驗成績八第3一 6 表二示ス.

第 3 表 ばらちふす菌

\begin{tabular}{|c|c|c|c|c|c|}
\hline 作用法 & $\begin{array}{c}\text { 作用 } \\
\text { 時間 }\end{array}$ & 20 分 & 30 分 & 40 分 & 50 分 \\
\hline 對照 & $49^{\circ} \mathrm{C}$ & $\infty$ & ca. 6000 & ca. 500 & 0 \\
\hline 水素 & $49^{\circ} \mathrm{C}$ & $\infty$ & ca.1000 & 0 & 0 \\
\hline
\end{tabular}

第 5 表 腸ちふす菌

\begin{tabular}{|c|c|c|c|c|c|}
\hline 作用法 & $\begin{array}{c}\text { 作用 } \\
\text { 溫度 }\end{array}$ & 時分 & 30 分 & 40 分 & 50 分 \\
\hline 對炤 & $48^{\circ} \mathrm{C}$ & $\infty$ & ca.8000 & ca. 50 & 0 \\
\hline 水素 & $48^{\circ} \mathrm{C}$ & $\infty$ & ca. 100 & 0 & 0 \\
\hline
\end{tabular}

第 4 表＼cjkstart鼠ちふす菌

\begin{tabular}{|c|c|c|c|c|c|}
\hline 作用法 & $\begin{array}{c}\text { 作用 } \\
\text { 溫度 }\end{array}$ & 20 分 & 30 分 & 40 分 & 50 分 \\
\hline 對炤 & $50^{\circ} \mathrm{C}$ & $\infty$ & $\infty$ & ca. 300 & ca50 \\
\hline 水素 & $50^{\circ} \mathrm{C}$ & $\infty$ & $\infty$ & ca. 500 & 0 \\
\hline
\end{tabular}

第 6 表 ぱらちふすA菌

\begin{tabular}{|c|c|c|c|c|c|}
\hline 作用法 & $\begin{array}{c}\text { 作用 } \\
\text { 溫度 }\end{array}$ & 20 分 & 30 分 & 40 分 & 50 分 \\
\hline 對炤 & $49^{\circ} \mathrm{C}$ & $\infty$ & $\infty$ & $c a .1000$ & 0 \\
\hline 水素 & $4^{\circ} \mathrm{C}$ & $\infty$ & ca. 2000 & 0 & 0 \\
\hline
\end{tabular}

此ノ實驗成績 =於テ例へバ腸ちふす菌 =於テ，超音波ノミヨ作用セル對照二於テ40分間作 用ニテ猶少數ノ聚落习認ムルモ，瓦斯使用二在リテハ30分間作用 $=$ テ殆ント菌ハ死減ス。ば らちふす A 及 B 菌及鼠ちふす菌二於テモ瓦斯使用二於テハ超音波ノミ 比シ菌ノ死滅時間ノ短縮七ルラ認ム。

赤脷本型菌, 赤痢異型 I 及

第 7 表 赤脷本型菌

\begin{tabular}{|c|c|c|c|c|c|}
\hline 作用法 & $\begin{array}{c}\text { 作每度 } \\
\text { 時間 }\end{array}$ & 10 分 & 20 分 & 30 分 & 40 分 \\
\hline 對照 & $48^{\circ} \mathrm{C}$ & $\infty$ & $\infty$ & ca. 200 & 0 \\
\hline 水素 & $48^{\circ} \mathrm{C}$ & $\infty$ & ca.1000 & 0 & 0 \\
\hline
\end{tabular}

第 9 表 赤痢異型菌

\begin{tabular}{|c|c|c|c|c|c|c|}
\hline 作用法 & $\begin{array}{c}\text { 作用 } \\
\text { 溫度 }\end{array}$ & 10 分 & 20 分 & \multicolumn{2}{|c|}{30 分 } & 40 分 \\
\hline 對昭 & $48^{\circ} \mathrm{C}$ & $\infty$ & $\infty$ & ca. 1000 & 0 \\
\hline 水素 & $48^{\circ} \mathrm{C}$ & $\infty$ & ca. 6000 & ca. 50 & 0 \\
\hline
\end{tabular}

第 8 表 赤浰異型 I 菌

\begin{tabular}{|c|c|c|c|c|c|}
\hline \multicolumn{2}{|c|}{$\begin{array}{c}\text { 作用用法 } \\
\text { 溫度 }\end{array}$} & 成分分 & 20 分 & 30 分 & 40 分 \\
\hline 對炤 & $49^{\circ} \mathrm{C}$ & $\infty$ & $\infty$ & ca. 800 & 0 \\
\hline 水素 & $49^{\circ} \mathrm{C}$ & $\infty$ & ca. 8000 & 0 & 0 \\
\hline
\end{tabular}

第 10 表 大腸菌

\begin{tabular}{|c|c|c|c|c|c|}
\hline 作用法 & $\begin{array}{c}\text { 作用 } \\
\text { 洔間 }\end{array}$ & 10 分 & 20 分 & 30 分 & 40 分 \\
\hline 對炤 & $48^{\circ} \mathrm{C}$ & $\infty$ & $\infty$ & ca. 930 & 0 \\
\hline 水素 & $48^{\circ} \mathrm{C}$ & $\infty$ & ca.5000 & 0 & 0 \\
\hline
\end{tabular}


此ノ實驗 =於テモ, 例へバ赤痢本型菌＝在リテ超軘波 タミヨ作用七儿對照ニ於テハ, 30分 間作用 $=$ 在リテモ少數, 聚落 7 殘スモ瓦斯 7 使用七儿時八菌八完全 $=$ 死隇ス.

大腸菌 $=$ 於ヶル實驗成績八第 10 表 $=$ 示スガ如ク，瓦斯使用ノ際八 30 分間作用 $=$ 完全 $=$ 菌 八死滅スルモ對照二於テハ聚落ヨ認ム。

\section{第 3 項 球菌}

白色葡蒛狀球菌及溶血性連鎻壯球菌 =就キテ, 實驗成績八第 $11-12$ 表 $=$ 示ス.

第 11 表 白色葡葫狀球菌

\begin{tabular}{|c|c|c|c|c|c|}
\hline 作用法 & 作用 & 30 分 & 40 分 & 50 分 & 60 分 \\
\hline 對炤 & $53^{\circ} \mathrm{C}$ & $\infty$ & $\infty$ & ca.1000 & 0 \\
\hline 水素 & $53^{\prime} \mathrm{C}$ & $\infty$ & ca. 5000 & ca. 50 & 0 \\
\hline
\end{tabular}

第 12 表 溶血性連政狀球菌

\begin{tabular}{|c|c|c|c|c|c|}
\hline 作用法 & 作用時間 & 20 分 & 30 分 & 40 分 & 50 分 \\
\hline 對照 & $50{ }^{\circ} \mathrm{C}$ & $\mathrm{H}$ & + & + & - \\
\hline 水素 & $50^{\circ} \mathrm{C}$ & $\mathrm{H}$ & $\mathrm{H}$ & - & - \\
\hline
\end{tabular}

此ノ實驗成績ノ白色葡药狀球菌＝於ケル，50 分間作用ニアリテ對照ノ聚落數八約 1.000 ナ

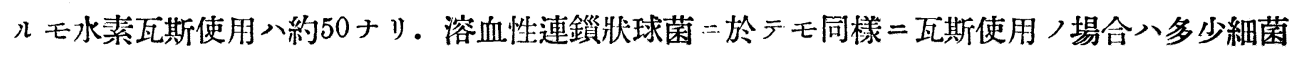
死隇 7 促進下。

\section{第 4 項 本節成績ノ小括}

以上水素瓦斯

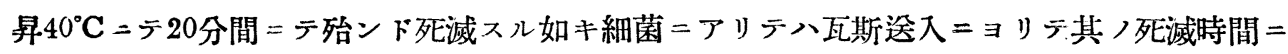
影響ヲ與へザルモ, 桿菌或ハ球菌ノ如ク超晋波=對スル抵抗比較的强キ菌種二在リテハ水素 瓦斯迩入

\section{第 2 節 酸素死斯ヨ以ラスル實驗}

\section{第 I 項 弧菌}

真正これら菌及非病原性弧菌赤穗株 $=$ 就キテノ實驗成績八第 13 表及第 14 表二示 $・$

第 13 表これら菌

\begin{tabular}{|c|c|c|c|c|}
\hline 作用法 & $\begin{array}{c}\text { 作角 } \\
\text { 時間 }\end{array}$ & 10 分 & 20 分 & 30 分 \\
\hline 對炤 & $41^{\circ} \mathrm{C}$ & $\infty$ & ca. 100 & 0 \\
\hline 酸素 & $41^{\prime} \mathrm{C}$ & $\infty$ & 0 & 0 \\
\hline
\end{tabular}

第 14 表 赤穗株

\begin{tabular}{|c|c|c|c|c|}
\hline 作用法 & 作用 & 10 分 & 20分 & 30 分 \\
\hline 對炤 & $40^{\circ} \mathrm{C}$ & $\infty$ & ca. 5000 & 0 \\
\hline 酸素 & $40^{\circ} \mathrm{C}$ & $\infty$ & ca. 1000 & 0 \\
\hline
\end{tabular}

作用時 溫度上昇 $41^{\circ} \mathrm{C}=$ 於テ，只超音波ノミヨ作用スルトキこれら菌二於テハ 20 分間作用 二在リテ猶僅カ二聚落 
(504)

㑛用ノ際=於らル菌集落數ハ $1 / 5=$ 減少セリ。

\section{第 2 項 桿菌}

腸ちふす菌・ばらちふす A 及 B 菌, 鼠ちふす菌二就キテノ實驗成績八第 15一18 表二示 ス.

第 15 表 腸ちふす菌

\begin{tabular}{|c|c|c|c|c|c|}
\hline 作用法 & 作用 & 20分 & 30 分 & 40 分 & 50 分 \\
\hline 對照 & $49^{\prime} \mathrm{C}$ & $\infty$ & ca.2000 & 0 & 0 \\
\hline 酸素 & $49^{\circ} \mathrm{C}$ & ca. 5000 & ca. 50 & 0 & 0 \\
\hline
\end{tabular}

第 17 表 ばらちふすB菌

\begin{tabular}{|c|c|c|c|c|c|}
\hline 作用法 & 作用時間 & 20 分 & 30 分 & 40 分 & 50 分 \\
\hline 對炤 & $49^{\circ} \mathrm{C}$ & $\infty$ & $\infty$ & $\mathrm{ca} .1000$ & 0 \\
\hline 酸素 & $49^{\circ} \mathrm{C}$ & $\infty$ & $\mathrm{ca} .5000$ & 0 & 0 \\
\hline
\end{tabular}

第 16 表 ばらちふすA菌

\begin{tabular}{|c|c|c|c|c|c|}
\hline 作用法 & 作角 & 20 分 & 30 分 & 40分 & 50 分 \\
\hline 對炤 & $48^{\circ} \mathrm{C}$ & $\infty$ & $\infty$ & ca.2000 & 0 \\
\hline 酸素 & $48^{\prime} \mathrm{C}$ & $\infty$ & $\overline{c a .5030}$ & 0 & 0 \\
\hline
\end{tabular}

第 18 表 鼠ちふす菌

\begin{tabular}{|c|c|c|c|c|c|}
\hline 作用法 & 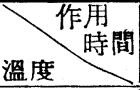 & 20 分 & 30分 & 40分 & 50 \\
\hline 對照 & $50^{\circ} \mathrm{C}$ & $\infty$ & $\infty$ & ca. 4000 & ca80 \\
\hline 酸素 & $50^{\circ} \mathrm{C}$ & $\infty$ & $\infty$ & ca: 200 & 0 \\
\hline
\end{tabular}

此ノ成績ニ於ヶル腸ちふす菌二在リテ，超音波ノミ ノ聚落习認ムモ，瓦斯使用ノ際八同時間ニう菌ハ殆ンド死滅ス。ばらちふす A及 B 菌鼠ち ふす菌 $=$ 於テモ同様二瓦斯使用 =在リテハ, 超音波ノミヨ作用セル時二比シ菌ノ死隇時間 短綰セルラ認ム。

赤痳本型菌，赤洞異型 I 及

第 19 表 赤峲本型菌

\begin{tabular}{|c|c|c|c|c|c|}
\hline 作用法 & 作角 & 10 分 & 20分 & 30 分 & 40 分 \\
\hline 對炤 & $48^{\circ} \mathrm{C}$ & $\infty$ & $\infty$ & ca. 3000 & 0 \\
\hline 酸素 & $48^{\prime} \mathrm{C}$ & $\infty$ & ca. 6000 & ca. 50 & 0 \\
\hline
\end{tabular}

第 21 表 赤瘚異型日菌

\begin{tabular}{|c|c|c|c|c|c|}
\hline 作用法 & 溫度 & 10 分 & 20 分 & 30 分 & 40 分 \\
\hline 對昭: & $48^{\circ} \mathrm{C}$ & $\infty$ & $\infty$ & ca. 5000 & 0 \\
\hline 酸素 & $48^{\circ} \mathrm{C}$ & $\infty$ & ca. 8300 & ca. 10) & 0 \\
\hline
\end{tabular}

第 20 表 赤琍異型 I 菌

\begin{tabular}{|c|c|c|c|c|c|}
\hline 作用法 & 作用 & 10 分 & 20 分 & 30分 & 40分 \\
\hline 對照 & $49^{\circ} \mathrm{C}$ & $\infty$ & $\infty$ & ca. 600 & 0 \\
\hline 酸素 & $49^{\circ} \mathrm{C}$ & $\infty$ & ca. 8000 & 0 & 0 \\
\hline
\end{tabular}

第 22 表 大腸菌

\begin{tabular}{|c|c|c|c|c|c|}
\hline 㡸用法 & \multicolumn{2}{|c|}{$\begin{array}{c}\text { 作用 } \\
\text { 溫度 }\end{array}$} \\
\hline 對照 & 49 間 & 20 分 & 20 & 30 分 & 40 分 \\
\hline 酸素 & $49^{\circ} \mathrm{C}$ & $\infty$ & $\infty$ & ca. 500 & 0 \\
\hline
\end{tabular}

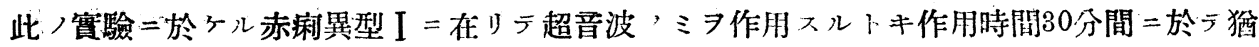
多數, 聚落习認ムモ，瓦斯使用七レトキ菌八完全一死喴・本型菌及異型二於テモ殆ン 
ト同樣ノ關係認メラレ, 又第22表二示ス大腸菌ノ實驗成績二於テモ亦瓦斯使用ノ際二於テハ 菌死隇時間 7 幾分短縮七ル

第 3 項 球菌 白色葡蔼狀球菌及溶血性連鎻球菌＝就キテノ實驗成績入第23-24表＝示ス.

第 23 表 白色葡蔼狀球菌

\begin{tabular}{|c|c|c|c|c|c|}
\hline 作用法 & $\begin{array}{c}\text { 作用溫度 } \\
\text { 時間 }\end{array}$ & 30 分 & 40 分 & 50 分 & 60 分 \\
\hline 對炤 & $52^{\prime} \mathrm{C}$ & $\infty$ & $\infty$ & $c a .1000$ & 0 \\
\hline 酸素 & $52^{\prime} \mathrm{C}$ & 0 & $\mathrm{ca} .3000$ & 0 & 0 \\
\hline
\end{tabular}

第 24 表 溶血性連鎻狀球菌

\begin{tabular}{|c|c|c|c|c|c|}
\hline 作用法 & $\begin{array}{c}\text { 作用 } \\
\text { 㬈度 }\end{array}$ & 20 分 & 30 分 & 40 分 & 50 分 \\
\hline 對照 & $50^{\circ} \mathrm{C}$ & $\mathrm{H}$ & $\mathrm{H}$ & $\neq$ & - \\
\hline 酸素 & $50^{\circ} \mathrm{C}$ & $\mathrm{H}$ & $\mathrm{H}$ & - & - \\
\hline
\end{tabular}

此ノ實驗成績二於ヶル白色葡萄状球菌 =在リテ, 對照ハ50 分間作用 $=$ 於テ聚落數約 1.000 ヨ戗スモ瓦斯使用ノノノ聚落 際八超揞波ノ菌死隇

\section{第 4 項 本節成績ノ小括}

以上酸素瓦斯使用ノ實驗二於テ, 弧菌ノ如キ超音波作用二對スル抵抗弱キ菌ニ在ツテハ明 瞅ナラザルモ, 桿菌, 球菌＝在リテハ明カ二超音波ノ菌死隇時間 短縮シ得ベシ。

\section{第 3 節 窒素死斯ヨテスル實驗}

\section{第 1 項 弧菌}

㣀正これら菌及非病原性弧菌习.以テスル賽驗成績八第25表及第26表二示ス.

第 25 表 これら菌

\begin{tabular}{|c|c|c|c|c|}
\hline 作用法 & $\begin{array}{c}\text { 作用 } \\
\text { 時間 }\end{array}$ & 10 分 & 20 分 & 30 分 \\
\hline 對炤 & $40^{\circ} \mathrm{C}$ & $\infty$ & ca. 3000 & 0 \\
\hline 禜素 & $40^{\circ} \mathrm{C}$ & $\infty$ & ca. 2000 & 0 \\
\hline
\end{tabular}

第 26 表 赤穗株

\begin{tabular}{|c|c|c|c|c|}
\hline 作用法 & 作角 & 10分 & 20 分 & 30 分 \\
\hline 對炤 & $40^{\circ} \mathrm{C}$ & $\infty$ & ca. 4000 & 0 \\
\hline 眥素 & $40^{\circ} \mathrm{C}$ & $\infty$ & ca.1000 & 0 \\
\hline
\end{tabular}

即チ超舀波ノミヨ作用七ルトキモ, 窒素瓦斯 間ハ殆ンド同様ナリ。

\section{第 2 項 桿菌}

䁑ちふす菌, ばらちふす A 及 B 菌. 鼠ちふす菌二就サテノ實嶮成績八第27一30表二示又, 
第 27 表 腸ちふす菌

\begin{tabular}{|c|c|c|c|c|c|}
\hline 作用法 & $\begin{array}{r}\text { 作用泪度 } \\
\text { 時間 }\end{array}$ & 20 分 & 39 分 & 40 分 & 50 分 \\
\hline 對照 & $45^{\circ} \mathrm{C}$ & $\infty$ & $\infty$ & ea. 4000 & 0 \\
\hline 筑素 & $45^{\circ} \mathrm{C}$ & $\infty$ & $\infty$ & ca.1000 & 0 \\
\hline
\end{tabular}

第 29 表ばらちふすB菌

\begin{tabular}{|c|c|c|c|c|c|}
\hline 作用法 & $\begin{array}{c}\text { 作用 } \\
\text { 溫度 }\end{array}$ & 30分 & 40 分 & 50 分 & 60分 \\
\hline 對照 & $43^{\prime} \mathrm{C}$ & $\infty$ & $\infty$ & ca. 1000 & 0 \\
\hline 丢素 & $43^{\prime} \mathrm{C}$ & $\infty$ & $\infty$ & ca. 500 & 0 \\
\hline
\end{tabular}

第 28 表 妨らちふすA菌

\begin{tabular}{|c|c|c|c|c|c|}
\hline 作用法 & $\begin{array}{c}\text { 作用㬈度 } \\
\text { 時間 }\end{array}$ & 20 分 & 30 分 & 40 分 & 50 分 \\
\hline 對照 & $48^{\prime} \mathrm{C}$ & $\infty$ & $\infty$ & ca. 100 & 0 \\
\hline 等素 & $48^{\prime} \mathrm{C}$ & $\infty$ & $\infty$ & ca. 500 & 0 \\
\hline
\end{tabular}

第 30 表 鼠ちふす菌

\begin{tabular}{|c|c|c|c|c|c|}
\hline 作用法 & 作用 & 溫度 \\
\hline 時間 & 30 分 & 40 分 & 50 分 & 60 分 \\
\hline 對昭 & $48^{\circ} \mathrm{C}$ & $\infty$ & $\infty$ & ca. 350 & 0 \\
\hline 等素 & $48^{\circ} \mathrm{C}$ & $\infty$ & $\infty$ & ca. 500 & 0 \\
\hline
\end{tabular}

此等 菌侏 $=$ 於テモ, 兩者間 $=$ 於テ菌死滅時間 =殆ンド相違 ヨ誠メ得ズ.

赤㢉本型菌, 赤㾥異型 I 及目 $=$ 就キテ，實驗成績八第 31 - 33 表二示 .

第 31 表 赤痢本型菌

第 32 表 赤浰異型 I 菌

\begin{tabular}{|c|c|c|c|c|c|}
\hline 作用法 & 作用 & 10 分 & 20分 & 30分 & 40 分 \\
\hline 對炤 & $48^{\circ} \mathrm{C}$ & $\infty$ & $\infty$ & ca. 500 & 0 \\
\hline 窒素 & $48^{\circ} \mathrm{C}$ & $\infty$ & co & ca. 100 & 0 \\
\hline
\end{tabular}

第 33 表 赤痢異型目菌

\begin{tabular}{|c|c|c|c|c|c|}
\hline 作用法 & 作用 & 溫度 \\
\hline 時間 & 10 分 & 20 分 & 30 分 & 40 分 \\
\hline 對照 & $48^{\circ} \mathrm{C}$ & $\infty$ & $\infty$ & ca. 650 & 0 \\
\hline 掌素 & $48^{\circ} \mathrm{C}$ & $\infty$ & $\infty$ & ca.1000 & 0 \\
\hline
\end{tabular}

\begin{tabular}{|c|c|c|c|c|c|}
\hline 作用法 & 作用 & 40 分 & 50分 & 60 分 & 70 \\
\hline 對照 & $44^{\prime} \mathrm{C}$ & $\infty$ & $\infty$ & ca. 600 & 0 \\
\hline 突素 & $44^{\prime} \mathrm{C}$ & $\infty$ & $\infty$ & ca.1000 & 0 \\
\hline
\end{tabular}

第 34 表 大腸菌

\begin{tabular}{|c|c|c|c|c|c|}
\hline 作用法 & 作角 & 10 分 & 20 分 & 30 分 & 40 分 \\
\hline 對炤 & $48^{\circ} \mathrm{C}$ & $\infty$ & $\infty$ & ca. 800 & 0 \\
\hline 萦素 & ${ }^{48} \mathrm{C}$ & $\infty$ & $\infty$ & ca.1000 & 0 \\
\hline
\end{tabular}

此等ノ菌株 =於テモ, 超亘波作用卜同時=窒素瓦斯 何等影響 樣ナリ.

\section{第 3 項 球菌}

白色葡萄狀球菌及溶血性連鎻狀球菌 =就キテノ實驗成績入第 35 -36表 =示ス.

第 35 表 白色葡萄狀球菌

\begin{tabular}{|c|c|c|c|c|c|}
\hline 作用法 & $\begin{array}{c}\text { 作用 } \\
\text { 溫度 }\end{array}$ & 30 分 & 40 分 & 50 分 & 60 分 \\
\hline 對昭 & $53^{\circ} \mathrm{C}$ & $\infty$ & ca. 5000 & ca. 300 & 0 \\
\hline 窒素 & $53^{\circ} \mathrm{C}$ & $\infty$ & 8 & ca.1000 & 0 \\
\hline
\end{tabular}

第 36 表 溶血性連鎻狀球菌

\begin{tabular}{|c|c|c|c|c|c|}
\hline 作用法 & $\begin{array}{c}\text { 作用 } \\
\text { 時間 }\end{array}$ & 20 分 & 30 分 & 40 分 & 50 分 \\
\hline 對昭 & $49^{\circ} \mathrm{C}$ & $\mathrm{H}$ & + & + & - \\
\hline 堂素 & $49^{\circ} \mathrm{C}$ & $\mathrm{H}$ & $+\mathrm{H}$ & + & - \\
\hline
\end{tabular}


尾䗁茂樹正

(507)

此等菌株ノ在リテモ弧菌, 桿菌ニ於ぐルト同椂ナリ。

第 4 項 本節成績ノ小括

窒素瓦斯迕入シツツ超亘波习作用モシメル場合，余ガ使用七ル範圍ノ細菌ノ死隇狀態八只 超晋波 $\ni$ 作用セシメタル場合卜何等特定 差異 7 見出シ得ズ.

第 4 節 炭酸瓦斯 $以$ 以テル實驗

第 I 項 弧菌

直正これら菌及非病原性弧菌赤穗侏＝關シテノ實驗成績八第37表及第 38 表 =示ス.

第 37 表これら菌

\begin{tabular}{|c|c|c|c|c|}
\hline 作用法 & 作用 & 10分 & 20 分 & 30 分 \\
\hline 對昭 & $39^{\prime} \mathrm{C}$ & $\infty$ & ca. 5000 & 0 \\
\hline $\begin{array}{l}\text { 岑酸 } \\
\text { 酉斯 }\end{array}$ & $39^{\circ} \mathrm{C}$ & $\infty$ & ca. 7000 & 0 \\
\hline
\end{tabular}

第 38 表 赤穗株

\begin{tabular}{|c|c|c|c|c|}
\hline 作用法 & 作用 & 10 分 & 20 分 & 30 分 \\
\hline 對炤 & $40^{\prime} \mathrm{C}$ & $\infty$ & ca. 630 & 0 \\
\hline $\begin{array}{l}\text { 炭酸 } \\
\text { 桼斯 }\end{array}$ & $40^{\prime} \mathrm{C}$ & $\infty$ & ca. 2000 & 0 \\
\hline
\end{tabular}

超音波ノミヨ作用スルトキこれら菌ニテハ作用時間 20 分間ニシテ聚落約 5.000 ナルモ炭 酸瓦斯使用ノ際八約 7.000 ヨ示シ，赤穗株ノ實驗 =於テモ亦同樣 $=$ 對照 $=$ 比シ僅カ $=$ 聚落

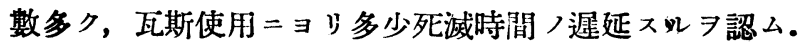

\section{第 2 項 桿菌}

腸ちふす菌, ばらちふす A B B 菌, 鼠ちふす菌=就キテノ實驗成績八第39-42表二示ス.

第 39 表 腸ちふす菌

\begin{tabular}{|c|c|c|c|c|c|}
\hline 作用法 & 作角時間 & 30 分 & 40 分 & 50 分 & 60 分 \\
\hline 對炤 & $44^{\circ} \mathrm{C}$ & $\infty$ & $c a .7000$ & 0 & 0 \\
\hline $\begin{array}{c}\text { 炭酸 } \\
\text { 互斯 }\end{array}$ & $44^{\circ} \mathrm{C}$ & $\infty$ & $\infty$ & $c a .1500$ & 0 \\
\hline
\end{tabular}

第 41 表ばらちふすB菌

\begin{tabular}{|c|c|c|c|c|c|}
\hline 作用法 & 作闻 & 30 分 & 40 分 & 50 分 & 60 分 \\
\hline 對炤 & $48^{\prime} \mathrm{C}$ & $\infty$ & $\infty$ & ca. 850 & 0 \\
\hline $\begin{array}{l}\text { 岸酸 } \\
\text { 瓦斯 }\end{array}$ & $48^{\prime} \mathrm{C}$ & $\infty$ & $\infty$ & $\infty$ & ca.10u \\
\hline
\end{tabular}

第 40 表 ばらちふすA菌

\begin{tabular}{|c|c|c|c|c|c|}
\hline 作用法 & 作角 & 30 分 & 40 分 & 50分 & 60 分 \\
\hline 對炤 & $45^{\circ} \mathrm{C}$ & $\infty$ & $\infty$ & 0 & 0 \\
\hline 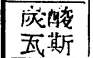 & $45^{\circ} \mathrm{C}$ & $\infty$ & $\infty$ & ca. 800 & 0 \\
\hline
\end{tabular}

第 42 表 鼠ちふす菌

\begin{tabular}{|c|c|c|c|c|c|}
\hline 作用法 & $\begin{array}{c}\text { 作用 } \\
\text { 溫度 }\end{array}$ & 30 分 & 40 分 & 50 分 & 6 分 \\
\hline 對炤 & $50^{\circ} \mathrm{C}$ & $\infty$ & $c a .5000$ & 0 & 0 \\
\hline $\begin{array}{c}\text { 崖酸 } \\
\text { 瓯斯 }\end{array}$ & $50^{\circ} \mathrm{C}$ & $\infty$ & $\infty$ & ca. 600 & 0 \\
\hline
\end{tabular}

超音波ノミヨ作用スルトキ，50分間＝テ菌八完全 $=$ 死滅スル炭酸瓦斯 7 同時二送入スルト キ猶約 1.500 聚落ヨ殘ス。ぱらちふす A及 B 菌, 鼠ちふす菌 於テモ同樣二炭酸瓦斯使用 
ニ在リテハ, 超音波ノミシ作用セル時二比シ幾分菌ノ死隇時間习僬延スルラ認ム。

赤痢本型菌, 赤淑異型 I 及

第 43 表 赤侘本型菌

\begin{tabular}{|c|c|c|c|c|c|}
\hline 作用法 & 作用時間 & 30 分 & 40 分 & 50 分 & 60 分 \\
\hline 對昭 & $45^{\circ} \mathrm{C}$ & $\infty$ & ca. 200 & 0 & 0 \\
\hline $\begin{array}{c}\text { 崖酸 } \\
\text { 互斯 }\end{array}$ & $45^{\circ} \mathrm{C}$ & $\infty$ & $\infty$ & ca. 1000 & 0 \\
\hline
\end{tabular}

第 45 表 赤浰暴型目菌

\begin{tabular}{|c|c|c|c|c|c|}
\hline 作用法 & 作用 & 30 分 & 40 分 & 50 分 & 60 分 \\
\hline 對炤 & $48^{\prime} \mathrm{C}$ & ca. 5000 & ca. 50 & 0 & 0 \\
\hline $\begin{array}{l}\text { 炭酸 } \\
\text { 瓦斯 }\end{array}$ & $48^{\prime} \mathrm{C}$ & $\infty$ & $\infty$ & ca. 100 & 0 \\
\hline
\end{tabular}

第 44 表 赤痢異型 I 菌

\begin{tabular}{|c|c|c|c|c|c|}
\hline 作用法 & 作用 & 40 分 & 50 分 & 60 分 & 70 分 \\
\hline 對㺼 & $45^{\circ} \mathrm{C}$ & ca.8J00 & ca.450 & 0 & 0 \\
\hline $\begin{array}{l}\text { 立酸 } \\
\text { 互斯 }\end{array}$ & $45^{\prime} \mathrm{C}$ & $\infty$ & $\infty$ & ca. 1000 & 0 \\
\hline
\end{tabular}

第 46 表 大腸菌

\begin{tabular}{|c|c|c|c|c|c|}
\hline 作用法 & 作用 & 30 分 & 40 分 & 50 分 & 60 分 \\
\hline 對炤 & $47^{\prime} \mathrm{C}$ & $\infty$ & ca .800 & 0 & 0 \\
\hline $\begin{array}{l}\text { 崖酸 } \\
\text { 酉斯 }\end{array}$ & $47^{\circ} \mathrm{C}$ & $\infty$ & $\infty$ & ca. 50 & 0 \\
\hline
\end{tabular}

此ノ實驗成績ニ於ヶル赤瘚異型 $I$ 在リテ超音波ノミヨ作用スルトキ60分間ニテ菌ハ完全 二死滅スルモ, 炭酸瓦斯 7 同時 =使用七儿時八聚落約 1.000 殘ス. 本型及異型 $\mathbf{n}=$ 於テモ 殆ンド同樣ナル關係ヨ認ム．第46表＝示ス八大腸菌＝就キテノ實驗成績ナルモ，瓦斯使用ノ 際ニ於テハ菌 $/$ 死堿時間 $\ni$ 幾分掘延スル 認ム.

\section{第 3 項 球菌}

白色葡萄狀球菌及溶血性連鎻狀球菌 =就キテノ賽驗成績八第47-48表 $=$ 示ス.

第 47 表 白色葡萄狀球菌

\begin{tabular}{|c|c|c|c|c|c|}
\hline 作用法 & $\begin{array}{c}\text { 作用 } \\
\text { 時間 } \\
\text { 溫度 }\end{array}$ & 50分 & 60 分 & 70分 & 80 分 \\
\hline 對炤 & $54, \mathrm{C}$ & ca. 5000 & 0 . & 0 & 0 \\
\hline $\begin{array}{l}\text { 炭酸 } \\
\text { 互斯 }\end{array}$ & $54^{\prime} \mathrm{C}$ & $\infty$ & $\infty$ & ca. 50 & 0 \\
\hline
\end{tabular}

第 48 表 溶血性連顴狀球菌

\begin{tabular}{|c|c|c|c|c|c|}
\hline 作用法 & 作用 & 20 分 & 30 分 & 40 分 & 50 分 \\
\hline 對炤 & $50^{\circ} \mathrm{C}$ & $\mathrm{H}$ & $H$ & + & - \\
\hline $\begin{array}{l}\text { 炭酸 } \\
\text { 瓦斯 }\end{array}$ & $50^{\circ} \mathrm{C}$ & $\mathrm{HH}$ & $\mathrm{HH}$ & $H$ & - \\
\hline
\end{tabular}

此ノ實噞成績 $=$ 於ヶル白色葡萄狀球菌 $=$ 在リテ, 對照入 60 分間作用 $=$ テ完全 $=$ 菌八死隇 . ルモ炭酸瓦斯使用入際八70分間作用=テモ猶僅少ノ聚落 7 認ム.

\section{第 4 項 本節成績ノ小括}

以上炭酸瓦斯使用ノ實驗 $=$ 於テ，弧菌ノ如キ短時間ニテ死隇スル菌ニテハ明カナラザルモ, 桿菌球菌 $=$ 於テハ明カ $=$ 菌死隇時間逮延スル

\section{第 3 節 結論}

以上弧菌 2 菌重, 桿菌 8 菌重, 球菌 2 菌偅合計 12 菌株 7 使用シ, 其等菌洙 24 時間培養 
菌苔ヨトリ之レヨ生理的食監水 $1 \mathrm{cc}$ 中 $1 \mathrm{mg}$ /割合二浮游七シメ, 之レ二超音波ノミ セルモノヨ對照トシテ, 作用ト同時二水素, 酸素, 窒素及炭酸瓦斯 7 通ゼルモノト比較シテ 死隇ノ狀態 $ヨ$ 檢シタルニ次ノ如キ結論二到達セリ.

1, 酸素及水素瓦斯八. 細菌ノ死滅時間 $\Rightarrow$ 幾分短縮 $\wedge$.

2, 窒素瓦斯ハ殆ンド影響ナシ。

3 , 炭酸瓦斯 $=ア リ テ ハ$ 却ツテ死隇時間八遲延ス.

4 , 以上 $1,2,3$, 八影響八桿菌又八球菌ノ如キ比較的超音波 $=$ 對ス儿抵抗强キ紐菌ノ種 類ニ於テハ明膫ナルモ。弧菌ノ如キ抵抗薄弱ナル細菌ノ種類＝於テハ明瞭ナラズ.

脫稿二當リ御懇切ナル御校閱ヨ唇フセル京都帝國大學醫學部微生物學教室木村教授二深謝 シ。常二不斷ノ御指導卜嚴正ナル御校閱

文 献 後 出 